$\underline{\text { Review Articles }}$

\title{
HIV-Associated Venous Thromboembolism
}

Michele Bibas, Gianluigi Biava and Andrea Antinori.

Clinical Department, National Institute for Infectious Diseases “Lazzaro Spallanzani”, IRCCS, Rome, Italy

Correspondence to: Michele Bibas, MD. Clinical Department, National Institute for Infectious Diseases, "Lazzaro Spallanzani, IRCCS, Via Portuense 292 - 00149 Rome, Italy. Phone/Fax : +39 06 55170641. E-mail: michele.bibas@ @inmi.it

Competing interests: The authors have declared that no competing interests exist.

Published: July 8, 2011

Received: May 17, 2011

Accepted: June 24, 2011

Mediterr J Hematol Infect Dis 2011, 3: e2011030, DOI 10.4084/MJHID.2011.030

This article is available from: http://www.mjhid.org/article/view/8590

This is an Open Access article distributed under the terms of the Creative Commons Attribution License (http://creativecommons.org/licenses/by/2.0), which permits unrestricted use, distribution, and reproduction in any medium, provided the original work is properly cited.

Abstract: HIV infection has been recognized as a prothrombotic condition and this association has now been proven by a large number of studies with a reported VTE frequency among HIV-infected patients ranging from $0.19 \%$ to $7,63 \%$ /year. HIV infection is associated with a two to tenfold increased risk of venous thrombosis in comparison with a general population of the same age. Some risk factors demonstrated a strongest association with VTE such as, low $\mathrm{CD4}^{+}$cell count especially in the presence of clinical AIDS, protein S deficiency, and protein $\mathrm{C}$ deficiency. Whereas other risk factors are still controversial like protease inhibitor therapy, presence of active opportunistic infections and presence of antiphospholipid antibodies, including anticardiolipin antibodies and lupus anticoagulant. Physicians caring for HIV positive patients should be able to recognize and treat not only the well-known opportunistic infections and malignancies associated with this chronic disease, but also be alert to the less well-known complications such as thromboses. Pulmonary embolism should be included in the differential diagnosis when patients with HIV/AIDS have unexplained dyspnea or hypoxemia. In younger individuals with VTE, especially men, without other identifiable risk factors for VTE, HIV should be considered. Because interactions between warfarin and antiretrovirals is possible, health care providers should also be alert to the potential of dangerously high or low INRs when they are giving anticoagulants to patients with HIV infection who are undergoing antiretroviral therapy.

Introduction: Human immunodeficiency virus (HIV) infection results from one of two similar retroviruses (HIV-1 and HIV-2) that destroy CD4+ lymphocytes and impair cell-mediated immunity, affecting multiple organ systems. HIV manifestation ranges from asymptomatic carriage to the acquired immune deficiency syndrome (AIDS), which is defined by serious opportunistic infections or cancers. In 2009, there were worldwide an estimated 33.3 million (31.4 million -35.3 million) of adults and children living with HIV, 2.6 million [2.3 million-2.8 million] people became newly infected with HIV, and 1.8 million (1.62.1 million) are the AIDS-related death among adults and children. ${ }^{1}$ Treatment with highly active antiretroviral therapy (HAART) has successfully prolonged the life expectancy of HIV-infected patients 
Table 1: Main studies on VTE incidence in HIV patients.

\begin{tabular}{|lccc|}
\hline Author & Years studied & Population Size & VTE Incidence \\
\hline Jenkins $^{\mathbf{8}}$ & 1991 & 243 & $3.29 \%$ \\
Laing $^{\mathbf{1 0}}$ & 1996 & 728 & $0,96 \%$ \\
Howling $^{\mathbf{1 0}}$ & 1999 & 3792 & $1,07 \%$ \\
George $^{\mathbf{1 1}}$ & 1999 & 650 & $0,19-1,07 \%$ \\
Sullivan $^{\mathbf{1 2}}$ & 2000 & 42935 & $0,26 \%$ \\
Saber $^{\mathbf{1 3}}$ & 2001 & 4752 & $0,95 \%$ \\
Saif $^{\mathbf{1 4}}$ & 2001 & 131 & $7,63 \%$ \\
Copur $^{\mathbf{1 5}}$ & 2002 & 362 & $2,76 \%$ \\
Fulz $^{\mathbf{1 6}}$ & 2004 & $13549-514$ & $2,0 \%-1,6 \%$ \\
Ahonkhai $^{\mathbf{1 7}}$ & $1989-2004$ & 160 & $0,54 \%$ \\
Malek $^{\mathbf{1 8}}$ & $1996-2004$ & 6944 & 0.52 \\
Crum-Cianflone $^{\mathbf{1 9}}$ & $1996-2007$ & 465 & $3,7 \%$ \\
Rasmussen $^{\mathbf{2 0}}$ & $1995-2007$ & 4333 & $8.0 \%-1,5 \% ;$ norm pop 0,3\% \\
\hline
\end{tabular}

and infection with the human immunodeficiency virus is increasingly becoming a chronic disease in the developed world. ${ }^{2.3}$ Improved survival has been followed by an increased and anticipated prevalence of non-AIDS related conditions, in particular cardiovascular disease is now a leading cause of morbidity and mortality among HIV-infected people. ${ }^{4}$

Epidemiology: Venous thromboembolism (VTE) is a common, serious disease with an estimated incidence rate in the general population of 1 per 1000 personyears of observation. ${ }^{5}$ Prevention and treatment of VTE are gaining attention because of an increase in frequency, cost, and risk factors. Furthermore VTE is a potentially preventable disease and it is of utmost importance to identify individuals in high-risk populations who may benefit from primary thromboprophylaxis. ${ }^{6,7}$ HIV infection has been recognized as a prothrombotic condition and this association has now been proven by a large number of studies. In fact many epidemiological studies reported on the occurrence of VTE among HIV-infected patients with a frequency ranging from 0.19 to 7,63 $\% /$ year. ${ }^{8-20}$ These studies (Table 1) estimates that the overall increase of the risk of VTE in HIV-infected patients was 2-10-fold higher than expected in general population. However many trials were limited by small sample size and a lack of a population based comparison control, and mainly were conducted in the pre-HAART era. Few studies were conducted in the more recent HAART era. ${ }^{8-20}$ Of interest recently Rasmussen found that the 5-year risk of VTE was 8.0\% in injecting drug users (IDU) HIV-infected patients, $1,5 \%$ in non-IDU HIV-infected patients and $0.3 \%$ in the population comparison cohort. ${ }^{20}$

Although HIV-infected patients are at increased risk for venous thromboembolism little work has been done on defining the exact mechanisms by which this phenomenon occurs, and still less has been done on evaluating the role thromboprophylaxis in HIVinfected individuals. Notably the 2008 American
College of Chest Physicians (ACCP) guidelines on antithrombotic and thrombolytic therapy are silent on this subject. ${ }^{7}$ Furthermore there are some important concerns about the therapy of HIV-related thromboses. The aim of this review is to provide an overview about the venous thromboembolism in HIV-infected individuals, trying to cover pathogenesis, prophylaxis and treatment issues.

Risk Factors for Thromboembolism in Hiv-Infected Patients: VTE is a multicausal disease and most commonly is the result of more than one "Hit". The probability of developing venous thromboses would depend on type and number of risk factors involved (Figure 1). Many established factors are known to increase the risk of VTE in general population. ${ }^{21}$ Furthermore several specific factors are thought to be associated with VTE in patients with HIV. For convenience we grouped them in three categories: those regarding the host, mainly defining a hypercoaglulable state and endothelial dysfunctions, those regarding the HIV diseases state, and those regarding the therapy whether HAART or other.

\section{Host Risk Factors:}

Age: In the developed world advancing age is a well known risk for thrombosis in general population. The incidence of venous thromboembolism increase dramatically as the population ages, from $0,001 \%$ a year in childhood to nearly $1 \%$ a year in the elderly. ${ }^{22}$ Because most HIV infected people are relatively young, their risk of DVT should be expected to be lower than the overall incidence. Conversely many studies reported that $\mathrm{HIV}$-infected patients had a median age of 40 at time of venous thromboembolism that is 20 years younger than the median age of non infected patients. ${ }^{12,15}$ Furthermore patients younger than 50 years with HIV had a significantly higher incidence rate of VTE/year compared with agematched healthy controls. ${ }^{23}$ HIV-infected patient are in fact older than their chronological age and they 


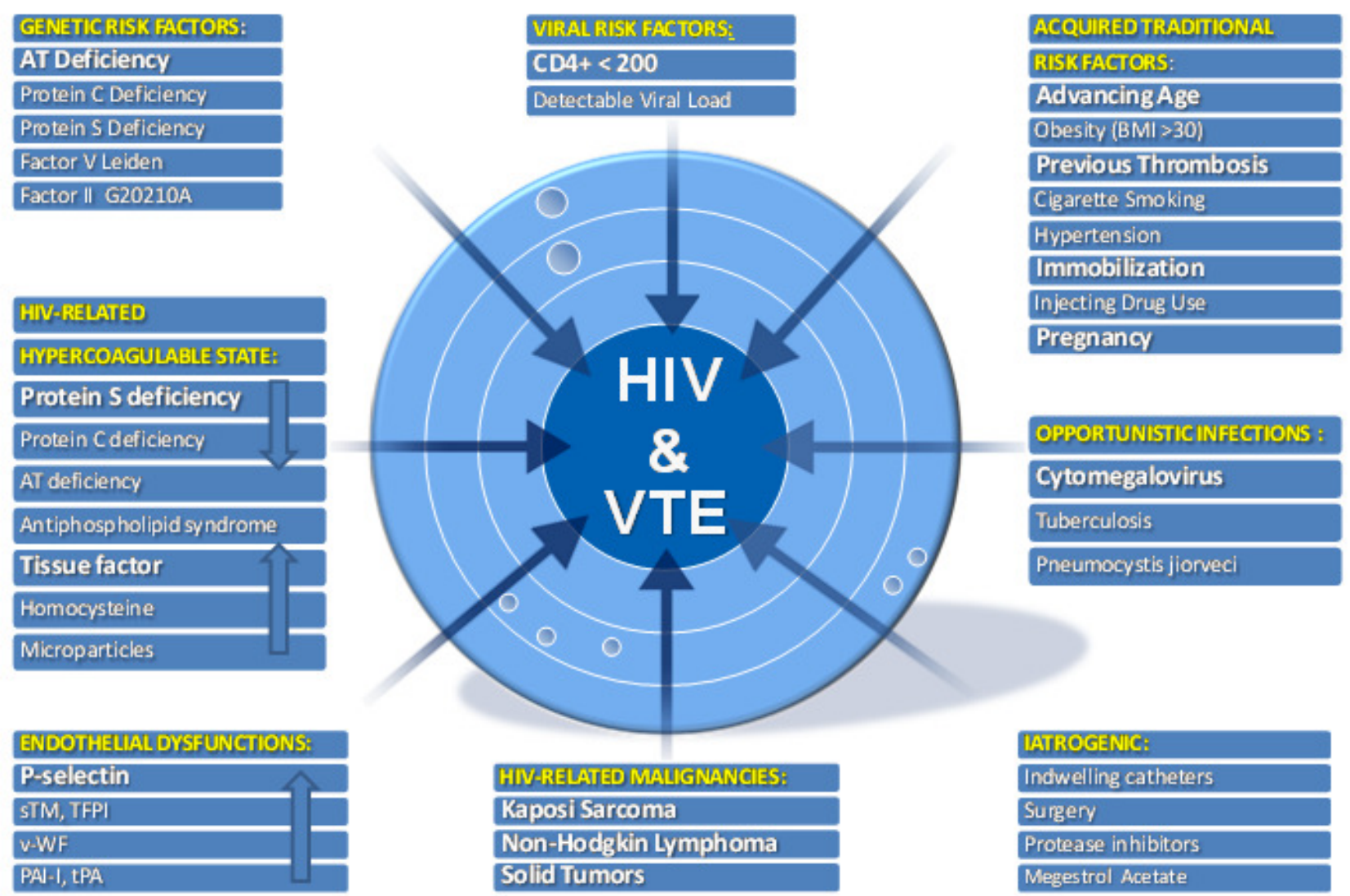

Figure 1: Multi-factorial etiology of HIV-related venous thromboembolism. AT, antithrombin; sTM, soluble thrombomodulin; TFPI, tissue factor pathway inhibitor; v-WF, von Willebrand Factor; PAI-I, plasminogen activator inhibitor-1; tPA, tissue plasminogen activator. Stronger risk factors for VTE are listed in bold.

experience the so-called "Premature Aging". In this immunological ageing the immune system has persistent defects even after years of treatment mediated viral suppression. Many are similar to those seen in normal ageing, but they occur at an earlier age than normal. ${ }^{24}$ Persistent abnormalities include low CD4:CD8 ratio, low naïve:memory cell ratio, expansion of CD28- effector $\mathrm{T}$ cells, reduced $\mathrm{T}$ cell repertoire, and reduced responsiveness to vaccines. Most of these abnormalities are seen only in patients who start treatment in late stage disease (CD4 nadir $<200$ cells). ${ }^{25}$ The heightened risk for premature aging is also the result of residual immunodeficiency and inflammation. ${ }^{26}$

Intravenous Drug Use: The intravenous use of recreational drugs is associated with considerable morbidity, a significant proportion of which may be from the drug itself. ${ }^{27}$ Intravenous drug use has been recently identified as an important cause of community-acquired VTE in young adults. ${ }^{28}$ In a recent elegant paper Rasmussen first show the impact of intravenous drug use on risk Of VTE in HIVinfected patients. ${ }^{20}$ This study found that the risk of VTE was nearly 15 times higher in IDU HIV-infected patients that in non IDU HIV-infected patients.

Hypercoagulable State: Protein S Deficiency: It is currently accepted that protein S (PS) deficiency is a significant contributor to the pro-coagulant nature of HIV infection. In fact protein S deficiency is the most consistently observed coagulation abnormality observed in HIV-infected patients, with a reported prevalence ranging from a $27 \%$ to a $76 \%$, with a $12 \%$ of those patients having a venous thromboembolism. ${ }^{29-}$ ${ }^{32}$ PS deficiency in HIV-positive patients is probably multi-factorial and the frequency of this alteration/deficiency has led to an extensive pursuit of potential mechanism. Type III PS deficiency is the most common abnormality found and characterized by a normal total protein $S$ level with a decrease in both free protein $\mathrm{S}$ and functional protein $\mathrm{S}$ activity. ${ }^{33}$ Decreased synthesis by the endothelial cells, hepatocytes and megakariocytes injured in HIV infection has been proposed..$^{30} \mathrm{~A}$ positive correlation between antibodies to PS and low levels of circulating free antigen has also been noted in symptomatic HIVinfected patients. ${ }^{34}$ Other authors suggested that tumor necrosis-factor-alpha (TNF- $\alpha$ ) can lower the levels of active protein $\mathrm{S}$ down-regulating the protein $\mathrm{S}$ 
synthesis in the endothelial cells. ${ }^{35}$ Another publication showed how the occurrence of PS deficiency might be linked to the presence of antiphospolipid antibodies. ${ }^{36}$ Protein C Deficiency: The relationship between protein $\mathrm{C}$ deficiency and VTE in HIV infection is not as clear as that of protein $\mathrm{S}$ deficiency, with a prevalence ranging from 0 to $14 \%$. However in one study a high prevalence of protein $\mathrm{C}$ deficiency was found in HIV patients who had VTE without other noted risk factors for venous thromboembolism. ${ }^{31}$ The mechanism of PC deficiency in HIV infected persons is multi-factorial, including altered synthesis and metabolism as well as low-grade disseminated intravascular coagulation (DIC) with consumptive coagulopathy. ${ }^{37}$

Antithrombin Deficiency: There is no direct evidence of HIV infection leading to Antithrombin deficiency. Acquired AT deficiency frequently occurs in the course of HIV disease as a consequence of associated conditions that cause decreased protein synthesis (liver diseases eg HCV coinfections and malnutrition), protein-losing nephropathies or enteropathies, consumptive states (malignancy, DIC, surgery). Nevertheless cases of AT deficiency in HIV patients who experienced thrombotic events have been reported. . $^{4,38,39}$

Antiphospholipid And Lupus Anticoagulant Antibodies: The antiphospholipid syndrome (APS) is an autoimmune disease associated to the appearance of two main circulating auto-antibodies, anticardiolipin antibodies (ACA) and lupus anticoagulant (LA). The frequency of APS in the general population is $2-4 \%$, and is clearly linked to increased risk of venous and arterial thrombosis. ${ }^{40}$ ACA have been reported in HIVinfected patients with a prevalence ranging from $7 \%$ to $94 \% .^{41}$ However there are both reports of no association $^{42,43}$ and positive association between having positive ACA and VTE in HIV+ patients. ${ }^{44,45}$ LA is much more variable in frequency and manifestation in $\mathrm{HIV}+$ patients. The incidence ranging from $0 \%$ to $72 \%$ but no pathogenic correlation was found with thromboses in two large series of HIV patients[ $]^{44,45}$ even if some case reports are found in the literature. ${ }^{46}$ Actually is thought that LA activity in those patients might be an epiphenomenon secondary to chronic immune stimulation in HIV infection.

Tissue Factor: Recently Funderburg et $\mathrm{al}^{47}$ found dramatically higher frequencies of monocytes expressing tissue factor (TF) in fresh blood samples from HIV-infected persons than in samples from uninfected controls. They postulated that a variety of bacterial toll-like receptor (TLR) ligands, such as peptidoglycans, lipopolysaccharide (LPS), and flagellins, are translocated through the damaged gut in chronic HIV infection and may drive immune activation (in addition to HIV viral Replication) and monocyte TF expression in this setting. ${ }^{48}$ The relevance of increased TF expression in HIV infection is underscored by the high levels of D-dimers in plasma and by the correlation between TF expression and D-dimer levels. HIV replication and systemic translocation of microbial products from the damaged gut, and the subsequent immune activation, contribute to a procoagulant state in $\mathrm{HIV}$-infected patients that is due, at least in part, to increased surface expression of TF on circulating monocytes. ${ }^{48}$

Microparticles: The term "microparticles" (MP) refers to a small $(<1 \mathrm{~m} \mu)$ membrane vesicles released from activated or apoptotic cells. ${ }^{49}$ The MPs may be generated from endothelial cells, vascular smooth muscle cells, platelets, tumor cells and from apoptotic CD4+ lymphocytes. ${ }^{50}$ In healthy individuals, very low levels of MPs are present in platelet-free plasma, conversely elevated levels have been identified in HIVpositive patients, but there is no clear evidence that this causes a rise in the risk of VTE. ${ }^{51}$

Homocysteine: Mild to moderate Hyperhomocysteinemia (HHcy) is relatively common in HIV-infected individuals, especially those using cART, with a prevalence ranging from 11 to $29 \% .^{52,53}$ Prospective cohort studies and an interventional trial in general population have estimated the increase in the risk of recurrence associated with raised homocysteine concentrations to be about 1 to 5 -fold. ${ }^{54,55}$ However, because vitamin supplementation (which reduces homocysteine concentrations) does not affect rate of recurrence, a causal relation between hyperhomocysteinemia and venous thrombosis remain uncertain. ${ }^{56} \mathrm{HHcy}$ is frequently present in HIV-patients without causing clinical manifestation suggesting that it may not be sufficient alone causing VTEs. However HHcy may add an additional risk among patients with other risk factors for venous clots.

Endothelial Dysfunction: Many studies showed a strong association between endothelial cells abnormalities and VTE in general population. ${ }^{57-59}$ Under normal conditions endothelial cells exert a vasodilatory, antiplatelet and local fibrinolytic tone that prevents platelet adhesion, leukocyte attachment, as well as blood coagulation.

A non-thrombogenic endothelial surface is maintained through a number of mechanisms, including the production of thrombomodulin (TM) (an activator of anticoagulant protein $\mathrm{C}$ ), the expression of heparan and dermatan sulphate (which accelerate the thrombin-inhibitory activity of antithrombin III and of heparin cofactor II), the constitutive expression of tissue factor pathway inhibitor (TFPI)(an inhibitor of tissue factor), and the local production of tissue plasminogen activator (tPA) and urokinase-type plasminogen activator (uPA), that are the main 
effectors of physiologic fibrinolysis. Crucial to many of the antithrombotic activities of endothelium are the synthesis of prostacyclin (PGI2) and of nitric oxide (NO).[60] In the context of VTE, a dysfunctional venous endothelium may express increased amounts of P-selectin, von Willebrand factor (vWF), tissue factor (TF), plasminogen activator inhibitor-1 (PAI-1), and factor $\mathrm{V}$, all of which may promote blood clotting and participate in the development of a thrombus. ${ }^{61}$ It is now well estabilished that the endothelium could be activated directly by HIV virus. In fact multiples studies reported the role of HIV in causing endothelial dysfunction. ${ }^{62,63}$

P-Selectin: In a recent study P-selectin was found in HIV-infected patients to be independently and most strongly associated with venous thrombosis. ${ }^{64}$ Stored in endothelial cells and platelet granules, P-selectin interacts with its receptor to promote a hypercoagulable environment by inducing the generation of prothrombotic microparticles from leukocytes and upregulation of tissue factor expression on monocytes. ${ }^{65}$ Prospective studies in HIV-uninfected participants with malignancies have demonstrated that P-selectin is significantly elevated in patients with an impending or acute VTE. Furthermore, P-selectin has been shown to have comparable diagnostic value to Ddimer in patients with confirmed DVTs. ${ }^{66}$

Miscellaneous Factors of Haemostasis: Various markers of endothelial cell damage such as von Willebrand factor (vWF), soluble thrombomodulin (sTM), adhesion molecule E-selectin, tissue-type plasminogen activator (tPA), plasminogen activator inhibitor (PAI-1),fibronectin, angiotensin-converting enzyme (ACE), and endothelin have been shown to be increased in the course of HIV-1 infection. ${ }^{67,68} \mathrm{HC}$ II deficiency was significantly more pronounced in AIDS patients compared with HIV patients and possible reason for HC II deficiency could be the decreased synthesis, enhanced proteolysis or consumption.[69] However no paper has shown a direct correlation between the low levels of HC II in HIV-positive patients and VTE. The secretion of tPA, (PAI-1), sTM, and $\mathrm{vWF}$ creates alterations in the coagulation cascade and could predispose to thrombosis. ${ }^{70-73}$ Furthermore, HIV gp120 could induce tissue factor expression in vascular SMCs, which may have potential effects on the arterial wall thrombogenicity. ${ }^{74}$ Anyway a link between in vitro findings and clinical events in HIV patients is still lacking.

\section{Viral Risk Factors:}

CD4+ Cell Count: The severity of the HIV infection appears to be of significance in association with VTE. In fact several studies confirmed that there is a higher incidence of venous thrombosis in patients with low
CD4 counts. ${ }^{12,37,75,76}$ In particular although the CD4 nadir and most recent CD4 count were both predictive in the univariate models, the strongest predictor in multivariate models was the CD4 cell count at the time of the VTE. ${ }^{14,19,77,78}$ Although the frequency of VTE is higher in the presence of lower $\mathrm{CD} 4^{+}$cell counts, there are reports of thrombosis occurring with $\mathrm{CD}^{+}$cell counts as high as 800 cells $/ \mathrm{mm}^{3}$, suggesting that the risk of thrombosis is not completely confined to patients with end-stage disease. ${ }^{19}$ The correlation between CD4 count and the risk for the development of thromboses may be related to an increasing hypercoagulable state found with progressive immune suppression and HIV disease progression. Various studies have documented that the abnormalities in proand anticoagulant factors, and as described previously, worsens as the disease progresses, swinging the pendulum in favor of thrombosis. $53,79,80$

Viral Load: Another indicator of high disease burden of HIV infection is viral load, also known as HIV RNA level. Low $\mathrm{CD}^{+}$cell counts and high viral loads are predictive of progression of HIV and typically complement each other in the absence of treatment. One group of authors concluded that a higher viral load, and lower $\mathrm{CD}^{+}$cell count, was associated with a higher risk of thrombosis, ${ }^{19}$ conversely others found no correlations. $^{14}$

Opportunistic Infection: In spite of the efficacy of HAART, HIV-positive individuals are at the greatest risk for developing opportunist infections depending to their immunologic status. So the concomitant presence of advanced HIV disease and opportunistic infections appears to be an additional risk factor for Thrombosis. ${ }^{8,13,14,76,79}$

VTE is most commonly reported with Cytomegalovirus and Pneumocystis jiroveci pneumonia (PCP) and Mycobacteriumaviumintracellulare. ${ }^{79,80}$

Cytomegalovirus: Cytomegalovirus active infection is a well-established cause of thrombosis and several case-studies described active cytomegalovirus infection in patient with VTE in general population. ${ }^{81-86}$ Regarding HIV-infected patients active cytomegalovirus infection has decreased substantially, in current HAART era, to less than 6 cases/100 personyears. ${ }^{87}$ In one study it was associated with a procoagulant state independently of stage of HIV disease. $^{88}$ The reported frequency of VTE in the presence of cytomegalovirus in HIV-positive individuals is approximately $9.8 \%$, with the majority of thrombosis associated with gastrointestinal-related disease. $^{12}$ 
Pneumocystis Jiroveci Pneumonia: Many authors reported the presence of active PCP during a VTE in HIV-infected patients. ${ }^{10,14,23,79}$ VTE associated with PCP may be secondary to the hypercoagulable state in patients with AIDS. In fact Pneumocystis jiroveci pneumonia patients with HIV have been shown to have an high rate of concurrent antiphospholipid syndrome that may increase the risk for developing VTE. ${ }^{89}$ Venous thromboembolism, specifically pulmonary embolism, in this population may remain underdiagnosed because of similar signs and symptoms of presentation between pulmonary embolism and PCP. ${ }^{90}$

Mycobacterium Tuberculosis and Intracellular
mycobacterium Avium: Mycobacterium-aviumintracellulare and Mycobacterium tuberculosis may induce anticardiolipin antibodies and a hypercoagulable state. Although anticardiolipin antibodies are found in these patients, a clear relationship with the appearance of thromboembolic complications was not demonstrated. ${ }^{91}$ Declining levels of anticardiolipin antibodies seem to occur after the initiation of effective treatment of underlying infection. ${ }^{47,92}$ Mycobacterium tuberculosis is able to activate macrophages directly and induces them to produce cytokines, especially TNF- $\alpha$, IL-1 and IL-6. TNF- $\alpha$ and IL-1 blocks the protein $\mathrm{C}$ anticoagulant pathway and can elicit tissue factor production on endothelium and monocytes. ${ }^{93}$ IL-6 can also stimulate new platelets formation which have increased sensitivity to thrombin activation and increased procoagulant activity. The prevalence of VTE in Tuberculosis patients is ranging from $0.6 \%$ to $3 \%$, while the prevalence of VTE in patients with coexisting HIV and tuberculosis is unknown. ${ }^{94,95}$

HIV-associated Malignancy: The risk of VTE in patients with cancer varies considerably between patients and even within an individual patient over time. Estimates ranging from 15 to $30 \%$ have been reported. ${ }^{96}$ It is well-known how patients with no identifiable risk factors who develops DVT may have an underlying occult malignancy ${ }^{97}$ People with HIV infection and AIDS have an elevated cancer risk. ${ }^{98}$ Compared with the general population, HIV-infected individuals have a 3640-fold increased risk of Kaposi sarcoma (KS), a 77-fold increased risk of non-Hodgkin lymphomas (NHL), and a six-fold increased risk of cervical cancer. ${ }^{99}$ These malignancies are AIDSdefining cancers, based on the Centers for Disease Control and Prevention (CDC) definition of AIDS. ${ }^{100}$ HIV-infected people also have an increased risk of a number of non-AIDS-defining cancers, including some associated with co-infections (eg, anal and oropharyngeal cancers associated with HPV infection, liver cancer associated with infection with hepatitis B and $\mathrm{C}$ viruses, and Hodgkin lymphoma associated with Epstein-Barr virus infection). ${ }^{101}$ Kaposi Sarcoma (KS) is the most common malignancy reported in literature associated with VTE in HIV-patients. Several reviews regarding thromboembolism in patients with $\mathrm{KS}$ in HIV-infected patients have reported an incidence of thrombosis ranging from $9.3 \%$ to $20 \% .^{13,23,102}$ The remaining malignancies were reported as single cases of primary CNS Lymphoma, B-cell non-Hodgkin lymphoma, Hodgkin disease, prostate cancer, anal cancer, colon cancer. ${ }^{13,19,23}$

\section{Drugs Risk Factors:}

HAART: HAART and in particular the use of protease inhibitors (PI) have been associated with thrombotic events. ${ }^{11,12,31,32}$ PI are thought to interfere with hepatic metabolism, specifically cytochrome P450 metabolism, and regulation of thrombotic proteins. This may ultimately cause a prothrombotic state in HIV-infected individuals and therefore increase the risk of a thrombotic episode. Otherwise they may either downregulate the anticoagulant effect within the body or generate endothelial or platelet dysfunction. ${ }^{14}$ Consistent data exist connecting protease inhibitors with lipodystrophy, and HIV-positive individuals with fat redistribution may be at increased risk for developing an abnormal coagulation profile, such as increased fibrinogen, D-dimer, plasminogen activator inhibitor-1, or protein S deficiency. ${ }^{103}$ Despite limited data, protease inhibitors indinavir and saquinavir, have been associated with an increased risk of VTE in the HIV-positive population, ${ }^{11,23,104,105}$ however a recent publication could prove no such association, suggesting that the association between HAART and risk of thrombosis may arise from mutual associations with other risk factors, in particular advanced disease. ${ }^{19}$

Megestrol: Megestrol acetate is a synthetic, orally active, progestational agent, used widely in the treatment of metastasic breast cancer. It has also been reported to stimulate appetite and weight gain in patients with AIDS-related anorexia and/or cachexia. In these groups of patients thromboembolic phenomena as adverse events potentially related to megestrol have been reported. ${ }^{106,107}$

Clinical Presentation: Clinicians should be alert to unprovoked thrombosis as a possible complication of AIDS and consider this in the differential diagnosis of patients with HIV infection. It is possible that the incidence of thromboembolic disease in those patients have been underestimated either due to the clinical 
picture mimicking opportunistic infections (e.g., opportunistic pulmonary infection vs. PE) or not considering the less well-known complication such as venous thromboembolism. ${ }^{108}$ The clinical appearance and distribution of thrombosis reported in the literature is similar to non HIV-patients. ${ }^{14,19,23}$ Most commonly thromboses involve the popliteal and femoral veins followed by pulmonary emboli.[10,36] In addition, abdominal involvement may occur as portal or splenic vein thromboses. ${ }^{109,110}$ HIV-infected persons may experience recurrences with an incidence of recurrence rate ranging from $8 \%$ to $15 \% .^{12}$

Pregnancy: Venous thromboembolism (VTE), in women during pregnancy and puerperium, has been described in literature with an incidence of approximately 1-2 in 1000 pregnancies. Women are five times more likely to develop VTE during pregnancy or puerperium compared to non-pregnant women. A recent study reported the annual incidence of VTE in HIV-positive women during puerperium of 313/1000 person-years (95\% CI 65-915). ${ }^{111}$ According to this finding, HIV-positive pregnant women are 120fold more likely to develop VTE than HIV-positive controls, $^{12}$ whereas the risk is 157-fold higher compared to HIV-negative pregnant women. ${ }^{111}$

Management: The 2008 ACCP guidelines on antithrombotic and thrombolytic therapy do not mention HIV-infected patients. Nevertheless clinicians dealing with HIV must be aware that this high risk population needs particular attentions regarding antithrombotic prophylaxis and therapy looking at them in the same way as it would be for patients suffering from cancer. The management of proven VTE in HIV-infected patients should be the same as for the non HIV-patients, including long-term prophylaxis with low molecular weight heparin and warfarin for patients with recurrent thrombosis.

Antiretroviral therapy and warfarin drug interaction: Because of an increased risk of thromboembolism in patients with HIV/AIDS and the increasing longevity of the HIV-infected population receiving effective antiretroviral therapy, more HIV-positive patients will be receiving in the future concomitant oral anticoagulant and antiretroviral therapy.

The interaction between antiretroviral agents and other medications has been widely described. ${ }^{112}$ Interactions between warfarin and antiretrovirals is possible, given the influence of many antiretrovirals on CYP2C9 the enzyme responsible for the metabolism of the more active $\mathrm{S}$-enantiomer of warfarin. ${ }^{113}$

Among the antiretrovirals, interactions involving non-nucleoside reverse transcriptase inhibitors (NNRTIs) and protease inhibitors (PIs) with warfarin are most likely to occur. Inhibition or induction of metabolism requiring warfarin dosage adjustment may be observed, depending on the specific antiretroviral drug. Among the NNRTIs, induction of warfarin metabolism is likely with nevirapine. Inhibition of warfarin metabolism may occur with efavirenz, delavirdine, or etravirine, but more evidence is needed to characterize the nature and onset of these interactions. Interactions involving ritonavir-boosted PIs are most frequent when warfarin is initiated in patients receiving concurrent efavirenz therapy. It seems prudent to base warfarin dosage adjustments on International Normalized Ratio (INR) response rather than empirically beginning with a lower warfarin dose. Similarly, INR response should be used to guide warfarin dosage requirements in patients on nevirapine, nelfinavir, lopinavir/ritonavir, or other ritonavirboosted PIs rather than starting with higher baseline doses. $^{114-117}$

Health care providers should be alert to the potential for dangerously high or low INRs when they are giving anticoagulants to patients with HIV infection who are undergoing antiretroviral therapy. Perhaps alternative forms of anticoagulation, such as low-molecular-weight heparin (LMWH), should be considered in some cases in the HIV-infected population receiving antiretroviral therapy, given the absence of compliance in some HIV-affected subjects. LMWH should be a safer choice in those patients, always keeping in mind that HIV infection may be an independent risk factor for the development of heparininduced thrombocytopenia (HIT). ${ }^{118}$ Lastly the timing of administration of warfarin and certain antiretroviral agents should be staggered.

Conclusions: Currently available epidemiological evidence suggests that chronic HIV infection is associated with a two to tenfold increased risk of venous thrombosis in comparison with a general population of the same age. Some risk factors demonstrated a strongest association with VTE such as like a diagnosis of AIDS, low $\mathrm{CD}^{+}$cell count especially in the presence of clinical AIDS, protein $S$ deficiency, and protein $\mathrm{C}$ deficiency. (Figure 2) Whereas other risk factors are still controversial like protease inhibitor therapy, presence of active opportunistic infections and presence of antiphospholipid antibodies, including anticardiolipin antibodies and lupus anticoagulant. With this understanding, appropriate prophylactic measures can be instituted, which may include universal VTE prophylaxis with oral anticoagulants or low-molecular weight heparin on hospitalization and for high-risk outpatients. Physicians caring for HIV positive patients should be able to recognize and treat not only the well- 


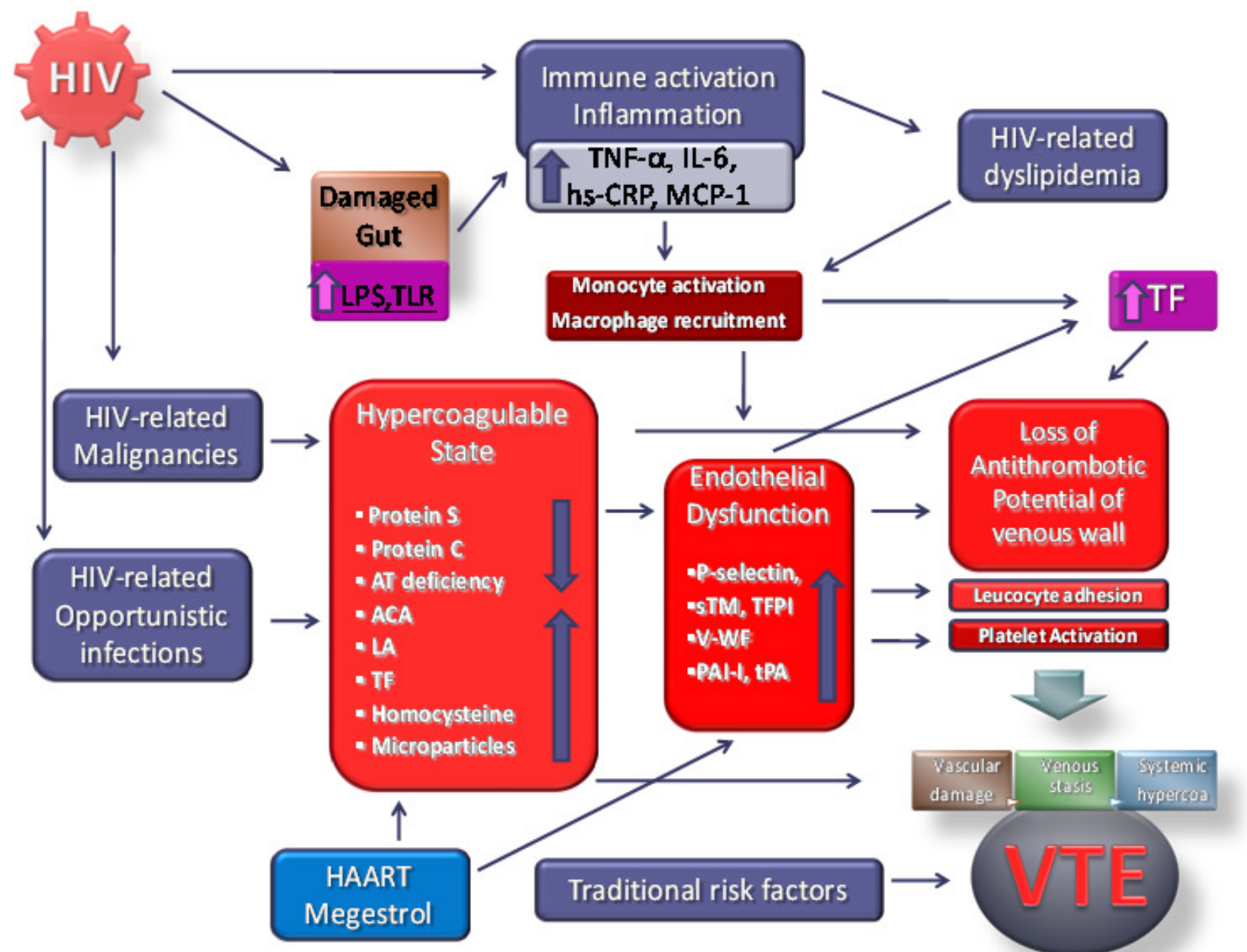

Figure 2: Diagram summarizing the pathogenesis of HIV-related VTE. HIV, human immunodeficiency virus; LPS, lipopolysaccharide; TLR, toll-like receptor; AT, antithrombin; ACA, anticardiolipin antibodies; LA, lupus anticoagulant; TF, Tissue Factor; TNF-a, tumor necrosis factor alpha; IL-6, interleukin six; hsCRP, high-sensitivity C-reactive protein; MCP1, monocyte chemotactic protein-1; sTM, soluble thrombomodulin; TFPI, tissue factor pathway inhibitor; v-WF, von Willebrand Factor; PAI-I, plasminogen activator inhibitor-1; tPA, tissue plasminogen activator

known opportunistic infections and malignancies associated with this chronic disease, but also be alert to the less well-known complications such as thromboses. Pulmonary embolism should be included in the differential diagnosis when patients with HIV/AIDS have unexplained dyspnea or hypoxemia. In younger individuals with VTE, especially men, without other identifiable risk factors for VTE, HIV should be considered.

\section{References:}

1. Global report: UNAIDS report on the global AIDS epidemic 2010. www.unaids.org (accessed 16 May 2011).

2. Palella FJ Jr, Delaney KM, Moorman AC, Loveless MO, Fuhrer J, Satten GA, Aschman DJ, Holmberg SD. Declining morbidity and mortality among patients with advanced human immunodeficiency virus infection. HIV Outpatient Study Investigators. N. Engl. J. Med. 1998 338: 853-860.

3. Murphy EL, Collier AC, Kalish LA, Assmann SF, Para MF, Flanigan TP, Kumar PN, Mintz L, Wallach FR, Nemo GJ. Highly active antiretroviral therapy decreases mortality and morbidity in patients with advanced HIV disease. Ann Inter Med
Finally new well-designed case control studies are needed to answer several open questions: Do traditional factors associated with increased VTE risk have the same impact in HIV patients? Does HAART contribute to VTE risk in HIV and How? Are traditional screening methods applicable in HIV? Are traditional VTE risk management strategies applicable in HIV?
2001 Jul 3 135(1): 17-26.

4. Mocroft A, Reiss P, Gasiorowski J, Ledergerber B, Kowalska J, Chiesi A, Gatell J, Rakhmanova A, Johnson M, Kirk O, Lundgren J. Serious fatal and non fatal non AIDS defining illnesses in Europe. J Acquir Immune Defic Syndr. 2010 Oct 1;55(2):262-70. doi:10.1097/QAI.0b013e3181e9be6b PMid:20700060

5. Naess IA, Christiansen SC, Romundstad P, Cannegieter SC, Rosendaal FR, Hammerstrøm J. Incidence and mortality of venous thromboembolism: a population based study. J Thromb Haemost. 2007;April 5(4):692-99 PMid:17367492 
6. Cohen AT, Tapson VF, Bergmann JF, Goldhaber SZ, Kakkar AK, Deslandes B, Huang W, Zayaruzny M, Emery L, Anderson FA Jr. Venous thromboembolism risk and prophylaxis in the acute hospital care setting (ENDORSE study): a multinational cross-sectional study. Lancet 2008;Feb 2 371: 387-394. doi:10.1016/S0140-6736(08)60202-0

7. Hirsh J, Guyatt G, Albers GW, Harrington R, Schünemann HJ, Antithrombotic and thrombolytic therapy: American College of Chest Physicians Evidence-Based Clinical Practice Guidelines (8th Edition). Chest. 2008 Jun;133(6 Suppl):110S-112S. Erratum in: Chest. 2008 Aug;134(2):473 doi:10.1378/chest.08-0652 PMid: 18574260

8. Jenkins RE, Peters BS, Pinching AJ. Thromboembolic disease in AIDS is associated with cytomegalovirus disease. AIDS 1991;Dec 5(12):1540-2. doi:10.1097/00002030-19911200000025 PMid:1667576

9. Laing RBS, Brettle RP, Leen CLS. Venous thrombosis in HIV infection, Int J STD AIDS 1996; Mar-April 7(2):82-5. doi:10.1258/0956462961917410 PMid:19244539

10. Howling SJ, Shaw PJ, Miller RF. Acute pulmonary embolism in patients with HIV disease. Sex Transm Infect 1999;75(1):25-9. doi:10.1136/sti.75.1.25 PMid:10448338 PMCid:1758180

11. George SL, Swindells S, Knudson R, Stapleton JT. Unexplained Thrombosis in HIV-infected Patients Receiving Protease Inhibitors: Report of Seven Cases. Am J Med 1999; Dec107(6):624-6. doi:10.1016/S0002-9343(99)00296-X

12. Sullivan PS, Dworkin MS, Jones JL, Hooper WG. Epidemiology of thrombosis in HIV-infected individuals. AIDS 2000;14:321-4. doi:10.1097/00002030-200002180-00015 PMid:10716509

13. Saber AA, Aboolian A, LaRaja RD, Baron H, Manna K. HIV/AIDS and the risk of deep vein thrombosis a study of 45 patients with lower extremity involvement. Am Surg 2001;67:645-7. PMid:11450780

14. Saif MW, Bona R, Greenberg B. AIDS and thrombosis: retrospective study of $131 \mathrm{HIV}$-infected patients. AIDS Patient Care STDS 2001:15(6):311-20. doi:10.1089/108729101750279687 PMid:11445013

15. Copur AS, Smith PR, Gomez V, Bergman M, Homel P. HIV infection is a risk factor for venous thromboembolism. AIDS Patient Care STDS. 2002;16(5):205-9. doi:10.1089/10872910252972258 PMid:12055028

16. Fultz SL, McGinnis KA, Skanderson M, Ragni MV, Justice AC.: Association of venous thromboembolism with human immunodeficiency virus and mortality in veterans. Am J Med 2004;Mar 15 116(6):420-3. doi:10.1016/j.amjmed.2003.10.011 PMid:15006592

17. Ahonkhai AA, Gebo KA, Streiff MB, Moore RD, Segal JB. Venous thromboembolism in patients with HIV/AIDS: a case control study. J Acquir Immune Defic Syndr 2008; 48:310-314. doi:10.1097/QAI.0b013e318163bd70 PMid:18197123 PMCid:2597553

18. Malek J., Rogers R., Kufera J., Hirson JM. Venous Thromboembolic disease in the HIV-infected patient. Am J Emerg Med. 2011 Mar;29(3):278-82. Epub 2010 Mar 26. doi:10.1016/j.ajem.2009.09.034 PMid:20825798

19. Crum-Cianflone NF, Weekes J, Bavaro M. Thromboses among HIV-infected patients during the highly active antiretroviral therapy era. AIDS Patient Care STDS. 2008 Oct;22(10):771-8. Review. doi:10.1089/apc.2008.0010 PMid:18783326 PMCid:2753452

20. Rasmussen LD, Dybdal M, Gerstoft J, Kronborg G, Larsen CS, Pedersen C, Pedersen G, Jensen J, Pedersen L, Sørensen HT, Obel N. HIV and risk of venous thromboembolism: a Danish nationwide population-based cohort study. HIV Med. 2011 Apr;12(4):202-10. doi: 10.1111/j.1468-1293.2010.00869.x. Epub $2010 \quad$ Aug 18. doi:10.1111/j.1468-1293.2010.00869.x PMid:20726905

21. Goldhaber SZ. Risk Factors for Thromboembolism . JACC 56,1 $2010 \quad$ June $29 \quad 1-7 \quad$ doi:10.1016/j.jacc.2010.01.057 PMid:20620709

22. Wilkerson WR, Sane DC. Aging and Thrombosis. Semin Thromb and haemost 2002; 28: 555-567. doi:10.1055/s-2002-36700 PMid:12536349

23. Jacobson MC, Debuze BJ, Aboulafia DM. Thrombotic complications in patients infected with HIV in the era of Highly active antiretroviral therapy: a case series. Clinc Infect Dis 2004;39:1214-22. doi:10.1086/424664 PMid:15486847

24. Appay V, Rowland-jones SL. Premature ageing of the immune system: the cause of AIDS? Trends Immunol 2002;23:580-5. doi:10.1016/S1471-4906(02)02338-4

25. Deeks SG, Phillips AN, HIV infection, antiretroviral treatment, ageing, and non-AIDS related morbidity. BJM Jan:26.338.288292

26. Kuller LH, Tracy R, Belloso W, De Wit S, Drummond F, Lane HC, Ledergerber B, Lundgren J, Neuhaus J, Nixon D, Paton NI, Neaton JD.- Inflammatory and coagulation biomarkers and mortality in patients with HIV infection. PLoS Med 2008:Oct 21 5(10):e203.

27. Lillam AL. Cardiovascular and Thrombosis pathology associated with cocaine use. Hematol Oncol Clin North Am 1993:7:114351. PMid:8294312

28. Syed FF, Beeching NJ. Lower-limb deep-vein thrombosis in a general hospital:risk factors, outcome and the contribution of intravenous drug use. QJM 2005;98: 139-145. doi:10.1093/qimed/hci020 PMid:15655094

29. Lafeuillade A, Alessi MC, Poizot-Martin I, Dhiver C, Quilichini R, Aubert L, Gastaut JA, Juhan-Vague I. Protein S deficiency and HIV infection.N Engl J Med 1991;324(17):1220. doi:10.1056/NEJM199104253241717

30. Lafeuillade A, Alessi MC, Poizot-Martin I, Boyer-Neumann C Zandotti C, Quilichini R, Aubert L, Tamalet C, Juhan-Vague I, Gastaut JA. Endothelial cell dysfunction in HIV infection. J Acquir Immune Defic Syndr 1992;5(2): 484-489. PMid: 1532830

31. Majluf-Cruz A, Silva-Estrada M, Sánchez-Barboza R, MontielManzano G, Treviño-Pérez S, Santoscoy-Gómez M, de ChávezOchoa AR, Corona-de la Peña N, Nieto-Cisneros L. Venous Thrombosis among patients with AIDS. Clin Appl Thromb $\begin{array}{lll}\text { Hemost 2004;Jan 10(1):19-25. } & \end{array}$ doi:10.1177/107602960401000104 PMid:14979401

32. Lijfering WM, Ten Kate MK, Sprenger HG, Van der Meer J.: Absolute risk of venous and arterial thrombosis in HIV-infected patients and effects of combination antiretroviral therapy. J Thromb Haemost 2006;4:1928-30. doi:10.1111/j.15387836.2006.02047.x PMid:16961600

33. Anderson J.A.M., Weitz J.I., Hypercoagulable States. Clin Chest Med 31 (2010) 659-673 doi:10.1016/j.ccm.2010.07.004 PMid:21047574

34. Sorice M, Griggi T, Arcieri P, Circella A, d'Agostino F, Ranieri M, Modrzewska R, Lenti L, Mariani G. The role of Anticardiolipin and anti-Protein S Antibodies. Thromb Res 1994; Feb 15 73(3-4):165-75. doi:10.1016/0049-3848(94)90095-7

35. Hooper WC, Phillips DJ, Ribeiro MJ, Benson JM, George VG, Ades EW, Evatt BL. Tumor Necrosis Factor-alfa downregulates Protein S secretion in Human Microvascular and Umbelical Vein Endothelial Cells but not in the HepG-2 Hepatoma Cell Line. Blood 1994:Jul 15 84(2) :483-9.

36. De Larranaga GF., Forastiero RR., Carreras LO., Alonso BS Different types of antiphospholipid antibodies in AIDS.: A comparison with syphilis and the antiphospholipid syndrome. Thromb Res 1999 Oct 1;96 (1) 19-25 doi:10.1016/S0049-3848(99)00059-6

37. Feffer SE, Fox RL, Orsen MM, Harajai KJ.,Glatt AE Thrombotic tendencies and correlation with clinical status in patients infected with HIV. South Med J 1995;88(11):11261130. doi:10.1097/00007611-199511000-00008 PMid:7481983

38. Demers C, Ginsberg JS, Hirsh J, Henderson P, Blajchman MA. Thrombosis in AT III deficiency persons. Report of a large kindred and literature review. Ann Inter MeD 1992 :116: 754 761.

39. Flinn WR., McDaniel MD, Yao JS. Antithrombin III deficiency as a reflection of dynamic protein metabolism in patients undergoing vascular reconstruction. J Vasc Surgery $1984 ; 125$ 888-895.

40. Espinosa G., Cervera R. Antiphospholipid syndrome: frequency, main cause and risk factors of mortality. Nat Rev Rheaumatol 6,296-300 2010. doi:10.1038/nrrheum.2010.47 PMid:20386563

41. Sene D., Piette JC, Cacoub P. Antiphospholipid antibodies, antiphospholipid syndrome and infections. Autoimmune Rev 2008;7:272-7 doi:10.1016/j.autrev.2007.10.001 PMid:18295729 
42. Galrão L, Brites C, Atta ML, Atta A, Lima I, Gonzalez F, Magalhães F, Santiago M. Antiphospholipid antibodies in HIVpositive patients. Clin Rheumatol. 2007 Nov;26(11):1825-30. Epub 2007 Feb 28. doi:10.1007/s10067-007-0581-6 PMid:17332976

43. Palomo I, Alarcón M, Sepulveda C, Pereira J, Espinola R, Pierangeli S. Prevalence of antiphospholipid and antiplatelet antibodies in human immnunodeficiency virus(HIV)-infected Chilean Patients. J Clin Lab Anal 2003:17(6)209-15 doi:10.1002/jcla.10093 PMid:14614742

44. Leder AN, Flansbaum B., Zandman-Goddard G., Asherson R, ShoenfeldY. Antiphospolipid syndrome induced by HIV. Lupus 2001;10:370-4. doi:10.1191/096120301669209574 PMid:11403270

45. Uthman IW, Gharavi AE. Viral infections and antiphospholipid antibodies. Semin Arthritis Rheum 2002;31:256-63 doi:10.1053/sarh.2002.28303 PMid:11836658

46. Shahnaz S., Parikh G, Opran A. Antiphospholipid antibody syndrome manifesting as a deep venous thrombosis and pulmonary embolism in a patient with HIV. Am J Med Sci. 2004; 327:231-2 doi:10.1097/00000441-200404000-00010 PMid: 15084920

47. Funderburg NT, Mayne E, Sieg SF, Asaad R, Jiang W, Kalinowska M, Luciano AA, Stevens W, Rodriguez B, Brenchley JM, Douek DC, Lederman MM. Increased tissue factor expression on circulating monocytes in chronic HIV infection: relationship to in vivo coagulation and immune activation. BLOOD 2010 14:115: 161-167.

48. Garcia F, Fumero E., Gatell JM. Immune modulators and treatment interruption. Curr Opin HIV/AIDS 2008;3(2):124-130

49. Morel O, Toti F, Hugel B, Bakouboula B, Camoin-Jau L, Dignat-George F, Freyssinet JM. Procoagulant microparticles: disrupting the vascular homeostasis equation. Arterioscler. Thromb.Vasc.Biol. $2006 \quad 26(12) 2594-604$ doi:10.1161/01.ATV.0000246775.14471.26 PMid:16990554

50. Mackman N., Tilley RE, Key Ns. Role of the extrinsic pathway of blood coagulation in hemostasis and thrombosis. Arterioscler. Thromb. Vasc. Biol. 2007 doi:10.1161/ATVBAHA.107.141911 PMid:1755665

51. Eyal A., Velelr M. HIV and venous thrombotic events. S Afr J Surg. 2009;47(2) 54-56. PMid:19626781

52. Bernasconi E, Uhr M, Magenta L, Ranno A, Telenti A Homocysteinemia in HIV-infected patients treated with highly active antiretroviral therapy. AIDS 2001:15:1081-1082. doi:10.1097/00002030-200105250-00027 PMid:11400001

53. Guaraldi G, Ventura P, Garlassi E, Orlando G, Squillace N, Nardini G, Stentarelli C, Zona S, Marchini S, Moriondo V, Tebas P. Hyperhomocysteinemia inHIV-infected patients: determinants of variability and correlations with predictors of cardiovascular disease. HIV Medicine 2009 10, 28-34. doi:10.1111/i.1468-1293.2008.00649.x PMid:19125962

54. Eichinger S, Stümpflen A, Hirschl M, Bialonczyk C, Herkner K, Stain M, Schneider B, Pabinger I, Lechner K, Kyrle PA. Hyperhomocysteinemia is a risk factor of recurrent venous thromboembolism.Thromb Haemost 1998; 80: 566-69. PMid:9798970

55. den Heijer M, Willems HP, Blom HJ, Gerrits WB, Cattaneo M, Eichinger S, Rosendaal FR, Bos GM. . Homocysteine lowering by $\mathrm{B}$ vitamins and the secondary prevention of deep vein thrombosis and pulmonary embolism: a randomized, placebocontrolled, double-blind trial. Blood 2007; 109: 139-44. doi:10.1182/blood-2006-04-014654 PMid:16960155

56. Kyrle PA, Rosendaal FR., Eichinger S.: Risk assessment for recurrent venous thrombosis. Lancet 2010:376:2032-39. doi:10.1016/S0140-6736(10)60962-2

57. Gresele P, Momi S., Migliacci R.: Endothelium, venous thromboembolism and ischemic cardiovascular events.: Thromb Haemost 2010;103:56-61. doi:10.1160/TH09-08-0562 PMid:20062938

58. Migliacci R, Becattini C, Pesavento R, Davi G, Vedovati MC, Guglielmini G, Falcinelli E, Ciabattoni G, Dalla Valle F, Prandoni P, Agnelli G, Gresele P. Endothelial dysfunction in patients with spontaneous venous thromboembolism. Haematologica 2007;92:812-818. doi:10.3324/haematol.10872 PMid:17550854
59. Gresele P, Migliacci R, Vedovati MC, Ruffatti A, Becattini C, Facco M, Guglielmini G, Boscaro E, Mezzasoma AM, Momi S, Pengo V. Patients with primary antiphospholipid antibody syndrome and without associated vascular risk factors present a normal endothelial function. Thromb Res 2009; 123:444-451. doi:10.1016/j.thromres.2008.05.015 PMid:18617225

60. Wakefield TW., Myers DD, Henke PK., Mechanism of venous thrombosis and resolution. Arterioscler Thromb Vasc Biol 2008:28:387-391 doi:10.1161/ATVBAHA.108.162289 PMid:18296594

61. Pomerantz RJ, Kuritzkes DR, de la Monte SM, Rota TR, Baker AS, Albert D, Bor DH, Feldman EL, Schooley RT, Hirsch MS. Infection of the retina by human immunodeficiency virus type I. $\begin{array}{llllll}N & \text { Engl } & \text { J } & \text { Med } & 1987 & 317: 1643-47\end{array}$ doi:10.1056/NEJM198712243172607 PMid:3479685

62. Solages A, Vita JA, Thornton DJ, Murray J, Heeren T, Craven $\mathrm{DE}$, Horsburgh CR Jr. Endothelial function in HIV-infected persons. Clin Infect Dis 2006:42(9):1325-1332. doi:10.1086/503261 PMid:16586393 PMCid:2737346

63. Chi D, Henry J, Kelley J, Thorpe R, Smith JK, Krishnaswamy G. The effects of HIV infection on endothelial function. Endothelium 2000;7:223-42. PMid:11201521

64. Musselwhite LW, Sheikh V, Norton TD, Rupert A, Porter BO, Penzak SR, Skinner J, Mican JM, Hadigan C, Sereti I. Markers of endothelial dysfunction, coagulation and tissue fibrosis independently predict venous thromboembolism in HIV. AIDS $2011, \quad 25: 787-795 . \quad$ doi:10.1097/QAD.0b013e3283453fcb PMid:21412059

65. Polgar J, Matuskova J, Wagner DD. The P-selectin, tissue factor,coagulation triad. J Thromb Haemost 2005; 3:1590-1596. doi:10.1111/j.1538-7836.2005.01373.x PMid:16102023

66. Rectenwald JE, Myers DD Jr, Hawley AE, Longo C, Henke PK, Guire KE, Schmaier AH, Wakefield TW. D-dimer, P-selectin, and microparticles: novel markers to predict deep venous thrombosis. A pilot study. Thromb Haemost 2005; 94:13121317. PMid: 16411411

67. Ross AC, Armentrout R, O'Riordan MA, Storer N, Rizk N, Harrill D, El Bejjani D, McComsey GA. Endothelial activation markers are linked to HIV status and are independent of antiretroviral therapy and Lipoatrophy. J Acquir Immune Defic Syndr 2008; 49(5): 499-506 doi:10.1097/QAI.0b013e318189a794 PMid:18989230 PMCid:2778267

68. Schved JF, Gris JC, Arnaud A, Martinez P, Sanchez N, Wautier $\mathrm{JL}$, Sarlat C. von Willebrand factor antigen, tissue-type plasminogen activator antigen, and risk of death in human immunodeficiency virus 1-related clinical disease: independent prognostic relevance of tissue-type plasminogen activator. J Lab Clin Med 1992;120:411-419. PMid:1517688

69. Toulon P, Lamine M, Ledjev I, Guez T, Holleman ME, Sereni D, Sicard D. Heparin Cofactor II deficiency in patients infected with the Human Immunodeficiency Virus. Thromb Haemost 1993 70: 730-735. PMid:8128426

70. Rolinski B, Geier SA, Sadri I, Klauss V, Bogner JR, Ehrenreich $\mathrm{H}$, Goebel FD. Endothelin-1 immunoreactivity in plasma is elevated in HIV-1 infected patients with retinal microangiopathic syndrome. Clin Invest 1994;72:288-293. doi:10.1007/BF00180042 PMid:8043976

71. Seigneur M, Constans J, Blann A, Renard M, Pellegrin JL, Amiral J, Boisseau M, Conri C. Soluble adhesion molecules and endothelial cell damage in HIV infected patients. Thromb Haemost 1997;77:646-649 PMid:9134636

72. Hadigan C, Meigs JB, Rabe J, D'Agostino RB, Wilson PW, Lipinska I, Tofler GH, Grinspoon SS . Increased PAI-1 and tPA antigen levels are reduced with metformin therapy in HIVinfected patients with fat redistribution and insulin resistance. Clin Endocrinol Metab 2001;86:939-943. doi:10.1210/jc.86.2.939

73. Schecter AD, Berman AB, Yi L, Mosoian A, McManus CM, Berman JW, Klotman ME, Taubman MB. HIV envelope gp120 activates human arterial smooth muscle cells. Proc Natl Acad Sci USA 2001;98:10142-10147. doi:10.1073/pnas.181328798 PMid:11504923 PMCid:56929

74. Sugerman RW, Church JA, Goldsmith JC, Ens GE. Acquired protein $\mathrm{S}$ deficiency in children infected with human 
immunodeficiency virus. Pediatr Infect Dis J 1996;15:106-111 doi:10.1097/00006454-199602000-00003 PMid:8822281

75. Klein SK, Slim EJ, de Kruif MD, Keller TT, ten Cate H, van Gorp EC, Brandjes DP. Is chronic HIV infection associated with venous thrombotic disease? A systematic review. Neth J Med 2005;63:129-36. PMid:15869040

76. Karpatkin S, Nardi M, Green D. Platelet and coagulation defects associated with HIV-1-infection. Thromb Haemost 2002;88:389_ 401. PMid:12353066

77. Pinilla J, Hill AR.: Thromboembolism associated with acquired immunodeficiency syndrome [letter]. Chest 1992;102:1634. doi:10.1378/chest.102.5.1634a

78. Kiser LK., Badowski ME.: Risk factors for venous thromboembolism in patients with Human Immunodeficiency Virus Infection. Pharmacotheraphy.2010;30(12):1292-1302 doi:10.1592/phco.30.12.1292 PMid:21114396

79. Baker JV, Neuhaus J, Duprez D., Changes in Inflammatory and Coagulation Biomarkers: A Randomized Comparison of Immediate versus Deferred Antiretroviral Therapy in Patients With HIV Infection. J Acquir Immune Defic Syndr 2011;56:3643. doi:10.1097/QAI.0b013e3181f7f61a PMid:20930640

80. Abgueguen P, Delbos V, Chennebault JM, Payan C, Pichard E. Vascular thrombosis and acute cytomegalovirus infection in immunocompetent patients: Report of 2 cases and literature review. Clin Inf Dis 2003;36:E134-E139. doi:10.1086/374664 PMid:12766855

81. Lijfering WM, Sprenger HG, Son van WJ, Van Der Meer J. Mesenteric vein thrombosis associated with primary cytomegalovirus infection: A case report. Blood Coagul Fibrinolysis doi:10.1097/MBC.0b013e3281a3bef9

82. Abgueguen P, Delbos V, Ducancelle A, Jomaa S, Fanello S, Pichard E. Venous thrombosis in immunocompetent patients with acute cytomegalovirus infection: A complication that may be underestimated. Clin Microbiol Infect 2010;16:851-854. PMid:19686279

83. Tichelaar VY, Sprenger HG, Mäkelburg AB.: Active cytomegalovirus infection in patients with acute venous thrombosis: A case-control study. Am J Hematol. 2011 Feb 11. doi: 10.1002/ajh.22006. [Epub ahead of print] doi:10.1002/ajh.22006 PMid:21509792

84. Justo D, Finn T, Atzmony L, Guy N, Steinvil A.: Thrombosis associated with acute cytomegalovirus infection: a meta-analysis. Eur J Intern Med. 2011 Apr;22(2):195-9. Epub 2010 Dec 16.

85. Atzmony L, Halutz O, Avidor B, Finn T, Zimmerman O, Steinvil A, Zeltser D, Giladi M, Justo D. Incidence of cytomegalovirusassociated thrombosis and its risk factors: a case-control study. Thromb Res. 2010 Dec;126(6):e439-43.

86. Centers for Disease Control and Prevention.: Guidelines for prevention and treatment of opportunistic infections in HIV infected adults and adolescents. MMWR Recomm Rep 2009;58(RR-4):1-207. PMCid:2821196

87. Mulder R, Tichelaar YI, Sprenger HG, Mulder AB, Lijfering WM.: Relationship between cytomegalovirus infection and procoagulant changes in human immunodeficiency virusinfected patients. Clin Microbiol Infect. 2010 Nov 4. [Epub ahead of print]

88. Aboulafia DM, Bundow D, Waide S, Bennet C, Kerr D.: Initial observations on the efficacy of highly active antiretroviral therapy in the treatment of HIV-associated autoimmune thrombocytopenia. Am J Med Sci 2000;320:117-23. doi:10.1097/00000441-200008000-00010 PMid:10981487

89. Rosen MJ. Respirology.: Pulmonary complications of HIV infection.2008 Mar;13(2):181-90. Review.

90. Santiago MB., Cossermelli W.,Tuma MF., Pinto MN., Oliveira RM.: Anticardiolipin antibodies in patients with infectious diseases. Clin. Rheumat., 8: 23-28, 1989. doi:10.1007/BF02031064 PMid:2501063

91. Cohen AJ, Philips TM, Kessler CM. Circulating coagulation inhibitors in the acquired immunodeficiency syndrome. Ann Intern Med 1986;104:175-80. PMid:3080933

92. Turken O, Kunter E, Sezer M, Solmazgul E, Cerrahoglu K, Bozkanat E, Ozturk A, Ilvan A. Haemostatic changes in active pulmonary tuberculosis. Int J Tuberc Lung Dis 2002 6(10):927932. PMid:1236558
93. White NW: Venous thrombosis and rifampicin. Lancet 1989.2:434-35

94. Ambrosetti M, Ferrarese M, Codecasa LR, Besozzi G, Sarassi A, Viggiani P, Migliori GB. Incidence of Venous Thromboembolism in Tuberculosis Patients. Respiration 2006, 73:396. doi:10.1159/000091188 PMid:16439829

95. Khorana AA. Connolly GC.: Assessing Risk of Venous Thromboembolism in the Patient With Cancer. J Clin Oncol 2009 27:4839-4847. doi:10.1200/JCO.2009.22.3271 PMid:19720906 PMCid:2764392

96. Scates SM. Diagnosis and treatment of cancer- related thrombosis. Hematol Oncol Clin North Am. 1992;6:1329-1339 PMid:1452515

97. Engels EA, Pfeiffer RM, Goedert JJ, Virgo P, McNeel TS, Scoppa SM, Biggar RJ; Trends in cancer risk among people with AIDS in the United States 1980-2002. AIDS. 2006;20(12):16451654. $\quad$ doi:10.1097/01.aids.0000238411.75324.59 PMid:16868446

98. Engels EA, Biggar RJ, Hall HI, Cross H, Crutchfield A, Finch JL, Grigg R, Hylton T, Pawlish KS, McNeel TS, Goedert JJ. Cancer risk in people infected with human immunodeficiency virus in the United States. Int J Cancer. 2008;123(1):187-194. doi:10.1002/ijc.23487 PMid:18435450

99. Schneider E, Whitmore S, Glynn KM, Dominguez K, Mitsch A McKenna MT. Revised surveillance case definitions for HIV infection among adults, adolescents, and children aged $<18$ months and for HIV infection and AIDS among children aged 18 months to $<13$ years-United States, 2008. MMWR Recomm Rep. 2008;57(RR-10):1-12.

100. Shiels MS, Pfeiffer RM, Gail MH, Hall HI, Li J, Chaturvedi AK, Bhatia K, Uldrick TS, Yarchoan R, Goedert JJ, Engels EA. Cancer Burden in the HIV-Infected Population in the United States.: J Natl Cancer Inst. 2011 May 4;103(9):753-62. Epub 2011 Apr 11. doi:10.1093/jnci/djr076 PMid:21483021

101. Kaufmann T, Nisce LZ, Metroka C.: Thromboembolism in AIDS-related Kaposi's sarcoma. JAMA 1991;266:2834 doi:10.1001/jama.266.20.2834

102. Barbaro G. Cardiovascular manifestations of HIV infection. Circulation 2002;106:1420-5. doi:10.1161/01.CIR.0000031704.78200.59 PMid:12221062

103. Lyonne L, Magimel C, Cormerais L, Trouillier S, Bocquier B, Zenut M, Jacomet C, Laurichesse H, Beytout J, Lesens O. Thromboembolic events at the time of highly active antiretroviral therapies against human immunodeficiency virus].Rev Med Interne. 2008 Feb;29(2):100-4. Epub 2007 Nov 26. French. doi:10.1016/j.revmed.2007.10.417 PMid:18164785

104. Shen YM, Frenkel EP. Thrombosis and a hypercoagulable state in HIV-infected patients. Clin Appl Thromb Hemost. 2004 Jul;10(3):277-80. doi: $10.1177 / 107602960401000311$ PMid: 15247986

105. Fernández Sánchez C, Marín Gámez N, López Martínez G Carbayo Gorriz C. Thrombophlebitis by megestrol acetate in patients with human immunodeficiency virus infection. Med Clin (Barc). 1998 Jun 20;111(2):76-7.

106. Force L, Barrufet P, Herreras Z, Bolibar I. Deep venous thrombosis and megestrol in patients with HIV infection. AIDS. 1999 Jul 30;13(11):1425-6. doi:10.1097/00002030-19990730000031 PMid:10449306

107. Nagaraja V, Terriquez JA, Gavini H, Jha L, Klotz SA. Pulmonary Embolism Mimicking pneumonia in HIV patient 2010 Case Report Med. 2010;2010:394546. Epub 2010 Jun 14.

108. Narayanan TS, Narawane NM, Phadke AY, Abraham P.: Multiple abdominal venous thrombosis in HIV-seropositive patient. Indian J Gastroenterol 1998;17:105-106 PMid:9695393

109. Soentjens P, Ostyn B, Van Outryve S, Ysebaert D, Vekemans M, Colebunders R. Portal vein thrombosis in a patient with HIV treated with a protease inhibitor-containing regimen. Acta Clin Belg 2006;61:24-29. PMid:16673613

110. Heit JA, Kobbervig CE, James AH, Petterson TM, Bailey KR, Melton LJ.: Trends in the incidence of venous thromboembolism during pregnancy or postpartum: a 30-year population-based study. Ann Intern Med 2005; 143:697-706. PMid:16287790 
111. Pham PA, Flexner C.: Emerging antiretroviral drug interactions. J Antimicrob Chemother. 2011 Feb;66(2):235-9. Epub 2010 Dec 5. doi:10.1093/jac/dkq448 PMid:21131695

112. Holbrook AM, Pereira JA, Labiris R, McDonald H, Douketis JD, Crowther M, Wells PS. Systematic overview of warfarin and its drug and food interactions. Arch Intern Med. 2005;165:10951106. doi:10.1001/archinte.165.10.1095 PMid:15911722

113. Fulco PP, Zingone MM, Higginson RT. Possible antiretroviral therapy-warfarin drug interaction. Pharmacotherapy 2008;28:945-9. doi:10.1592/phco.28.7.945 PMid:18576910

114. Bonora S, Lanzafame M, D'Avolio A, Trentini L, Lattuada E, Concia E, Di Perri G. Drug interactions between warfarin and efavirenz or lopinavir-ritonavir in clinical treatment. Clin Infect Dis 2008;46:146-7. doi: $10.1086 / 524086$
115. Gatti G, Alessandrini A, Camera M, Di Biagio A, Bassetti M, Rizzo F. Influence of indinavir and ritonavir on warfarin anticoagulant activity. AIDS 1998;12:825-6. PMid:9619821

116. Knoell KR, Young TM, Cousins ES. Potential interaction involving warfarin and ritonavir. Ann Pharmacother 1998;32:1299-302. doi:10.1345/aph.17456 PMid:9876810

117. Hughes CA, Freitas A, Miedzinski LJ. Interaction between lopinavir/ritonavir and warfarin. CMAJ 2007;177:357-9. doi:10.1503/cmaj.061284 PMid:17698824 PMCid:1942099

118. Thompson GR 3rd, Lawrence VA, Crawford GE. HIV infection increases the risk of heparin-induced thrombocytopenia. Clin Infect Dis. 2007 Nov 15;45(10):1393-6. Epub 2007 Oct 8 doi:10.1086/522761 PMid:17968841 